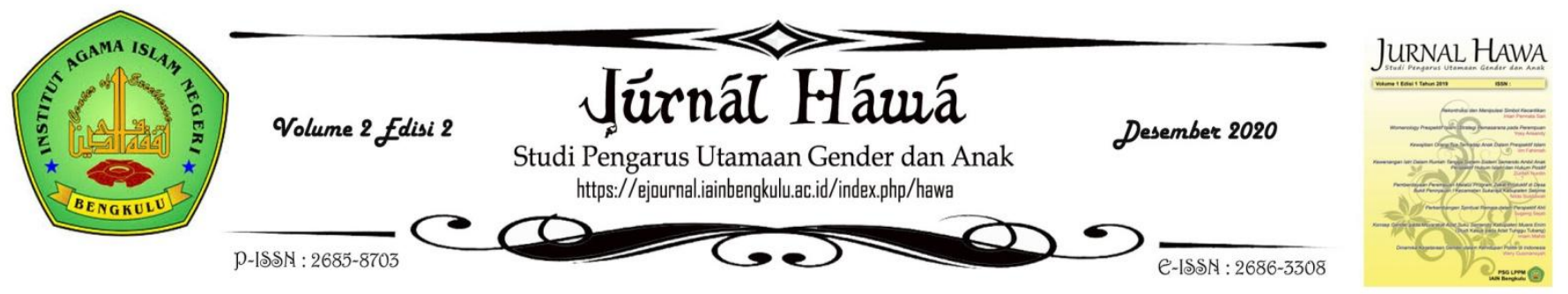

\title{
Self-monitoring Techniques: Perbedaan Peningkatan Achievement Motivation Siswa SMTA Berdasarkan Jenis Kelamin (Gender)
}

\author{
Prio Utomo ${ }^{1}$, Zubaidah ${ }^{2}$ \\ 11prio.utomo@iainbengkulu.ac.id, 2eda_rawas@yahoo.com \\ 1,2IAIN Bengkulu
}

\section{Info Artikel}

Diterima: Agustus

2020

Disetujui: September

2020

Dipublikasikan:

Desember 2020

\section{Keyword}

Self-monitoring
techniques,
achievement
motivation, male
and female
students (gender)

\section{Kata Kunei}

Teknik self-monitoring, achievement motivation, siswa laki-laki dan perempuan (gender)

\section{Abstract}

This research is motivated by the problem of low student achievement, the preliminary data from the pre-study found that the problem of low student achievement was caused by low student achievement motivation. The research objective was to determine the difference in the increase in student achievement motivation based on gender after being given selfmonitoring techniques. The research design used experimental research with the prestest and posttest design group. The research subjects of class XI SMA 03 Bengkulu City were 10 students consisting of 5 male students and 5 female students. The research instrument used a scale of achievement motivation and treatment guidelines. Data analysis used nonparametric statistical analysis with the Wilcoxom Signed Rank Test. Hypothesis testing shows that $H_{0}$ is rejected and $H_{1}$ is accepted, this means that there is no difference in the increase in student achievement motivation based on gender (gender) after being given the self-monitoring technique.The average value of increase in female students before (pretest) was 1.922 and after (posttest) was 3.184. Meanwhile, the average value of male students' increase before (pretest) was 1.931, and after (posttest) was 3.086. The conclusion of the study shows that there is no difference in the increase in the achievement motivation of male and female students after being given self-monitoring techniques and the role of gender (gender) does not have an effect on increasing student achievement motivation.

\section{Tbstrak}

Penelitian ini dilatar belakangi oleh masalah pencapaian prestasi akademik siswa rendah, data awal prapenelitian diperoleh temuan bahwa masalah pencapaian prestasi akademik siswa rendah disebabkan oleh achievement motivation siswa rendah. Tujuan penelitian untuk mengetahui perbedaan peningkatan achievement motivation siswa berdasarkan jenis kelamin (gender) setelah diberi teknik self-monitoring. Rancangan penelitian menggunakan experimental research dengan grup prestest and posttest design. Subjek penelitian siswa kelas XI SMA 03 Kota Bengkulu berjumlah 10 siswa terdiri dari 5 siswa laki-laki dan 5 siswa perempuan. Instrumen penelitian menggunakan skala achievement motivation dan pedoman perlakuan. Analisis data menggunakan analisis statistik nonparametrik dengan Wilcoxom Signed Rank Test. Pengujian hipotesis menunjukkan $\mathrm{H}_{0}$ ditolak dan $\mathrm{H}_{1}$ diterima, hal ini berarti tidak terdapat perbedaan peningkatan achievement motivation siswa berdasarkan jenis kelamin (gender) setelah diberi teknik self-monitoring. Nilai rata-rata peningkatan siswa perempuan sebelum (pretest) sebesar 1,922 dan sesudah (posttest) sebesar 3,184. Sedangkan nilai rata-rata peningkatan siswa laki-laki sebelum (pretest) sebesar 1,931, dan sesudah (posttest) sebesar 3,086. Simpulan hasil penelitian menunjukkan tidak terdapat perbedaan peningkatan achievement motivation siswa laki-laki dan perempuan setelah diberi teknik self-monitoring dan peran jenis kelamin (gender) tidak memberikan pengaruh terhadap peningkatan achievement motivation siswa. 


\section{Pendahuluan}

Pencapaian prestasi akademik siswa dipengaruhi oleh tingkat achievement motivation siswa. Siswa dengan achievement motivation tinggi tentu ia memiliki kegigihan dalam perilaku belajarnya, sebaliknya siswa dengan achievement motivation rendah perilaku belajarnya cenderung mengindari dan tidak tidak menyukai tugas-tugas akademik. Masalah achievement motivation siswa rendah telah menyebabkan pada penurunan prestasi akademik, Harian Kompas.com melansir hasil studi The Organisation for Economic Co-operation and Development (OECD) mengumumkan hasil Programme for International Studendt Assesment (PISA) tahun 2018 melaporkan perolehan peringkat prestasi siswa Indonesia tidak memuaskan dan masih di bawah rata-rata, hasil menunjukkan kemampuan literasi siswa berada pada urutan 66, matematika urutan 65 dan sains urutan 64 dari 72 Negara (Tirto.id, 2019).

Fenomena masalah achievement motivation siswa rendah disebabkan oleh beberapa faktor seperti regulasi diri siswa, hasil penelitian Aziroh (2018) mengungkap bahwa achievement motivation dan regulasi diri secara bersama-sama berpengaruh terhadap perilaku mencontek siswa-siswi, nilai variabel achievement motivation sebesar $68,46 \%$, regulasi diri sebesar 69,36\% dan perilaku mencontek sebesar 59,45\%. Faktor lainnya adalah model embelajaran guru, Hasil penelitian Suryana, Santyasa dan Gunadi (2019) mengungkap bahwa prestasi belajar yang lebih tinggi diraih siswa yang memiliki MBT (Motivasi Berprestasi Tinggi), sehingga terdapat pengaruh interaktif antara model pembelajaran dengan achievement motivation terhadap prestasi belajar siswa. Selanjutnya adalah faktor orang tua, Rugian (2019) mengungkap bahwa terdapat hubungan antara pola asuh orang tua dan achievement motivation dengan hasil belajar siswa. Aspek lainnya yang mempengaruhi adalah AQ, Hasil penelitian Setiarto (2020) menunjukkan terdapat hubungan antara AQ dengan motivasi berprestasi pada siswa MTsN 8 Madiun, semakin tinggi AQ siswa semakin tinggi pula achievement motivation siswa. Berdasarkan faktor-faktor tersebut, telah menyebabkan dan mengakibatkan achievement motivation siswa menjadi rendah.

\section{Achievement motivation merupakan} kecenderungan individu berusaha mencapai sukses dan memilih keberhasilan atau kegagalan tujuan akademik individu (Singh, 2011). Achievement motivation adalah hasrat keinginan yang menggerakkan motif tindakan untuk mencapai hasil belajar yang baik dan memuaskan yaitu berupa keberhasilan atau prestasi akademik maupun non akademik, keinginan mencapai keberhasilan atau prestasi diri inilah menggerakan pada motif tindakan berupa; perencanaan, semangat juang, usaha tindakan, umpan balik, dan evaluatif. Menurut Murray (Schunk, Pintrick dan Mee, 2008) mendefinisikan achievement motivation sebagai dorongan untuk menyelesaikan halhal yang sulit, mampu mengungguli, menguasai, menandingi, melampaui individu lain, mengatasi hambatan yang dihadapai, serta mencapai standar yang tinggi. 
Prio Utomo dan Zubaidah Self-monitoring Techniques: Perbedaan Peningkatan Achievement Motivation Siswa SMA Berdasarkan Jenis Kelamin (Gender)

Memperhatikan dan upaya mengatasi masalah achievement motivation pada siswa yang rendah, strategi yang dapat dilakukan dalam upaya meningkatkan achievement motivation siswa yaitu melalui cognitive behavior approach dengan menggunakan teknik self-monitoring, pendekatan ini merupakan peleburan antara pendekatan kognitif dan perilaku. Teknik self-monitoring sebagai suatu prosedur sistematis yang dilakukan siswa dengan cara memonitor perilaku mereka sendiri untuk menilai apakah suatu perilaku yang ditargetkan telah terjadi, proses monitoring ini dilakukan melallui beberapa cara tertentu (O'Reilly, et. al, 2002; Wilkinson, 2008). Menurut Peacock, et. al, (2010) mendefinisikan teknik self-monitoring adalah manajemen diri yang sering digunakan di dalam intervensi yang melibatkan pada dua proses, mencakup: pengamatan diri, dan perekaman diri. dalam penggunaannya, Miltenberger (2008) mengemukakan tujuan teknik self-monitoring sebagai preses menentukan target perilaku, perilaku bersaing, menetapkan sebuah tujuan, memonitor diri, penilaian fungsional, memilih strategi dalam manajemen diri secara tepat, mengevaluasi perubahan, mengevaluasi kembali strategi manajemen diri, menerapkan strategi pemeliharaan.

Dasar pertimbangan penggunaan teknik self-monitoring dalam upaya meningkatkan achievement motivation siswa didasari bahwa penggunaan teknik ini memfokuskan dan menekankan pada proses bagaimana siswa dapat memonitoring perilaku belajarnya, dan seberapa besar perubahan perilaku dari target yang dihasilkan. Dipertegas Graham dkk, mengemukakan teknik self-monitoring merupakan proses pemantauan diri yang mencakup dua jenis; pengamatan diri, individu mengamati secara sadar ada atau tidak dari perilaku sasaran yang dibuatnya. Perekaman diri, individu mencatat perilaku yang dilakukannya (Allinder dkk, 2000). Disamping itu, pertimbangan lain didasari dari hasil penelitian terdahulu menyimpulkan teknik self-monitoring teruji efektif meningkatkan perilaku belajar siswa. Hasil penelitian Dwindita dan Hildayani (2019) menunjukkan teknik self-monitoring efektif meningkatkan perilaku on-task siswa, hasil penelitian Putra dan Dharsana (2019) menunjukkan teknik Self Monitoring efektif meningkatkan self order siswa, hasil penelitian Isnannisa dan Hildayani (2019) menunjukkan teknik self-monitoring efektif untuk meningkatkan perilaku on-task siswa. Bertolak dari hasil penelitian terdahulu, melalui penggunaan teknik self-monitoring pada penelitian ini digunakan untuk mengetahui efektifitas peningkatan achievement motivation siswa.

Tujuan penelitian ini adalah untuk mengetahui perbedaan peningkatan achievement motivation siswa antara laki-laki dan perempuan setelah diberi teknik selfmonitoring. Hipotesis penelitian ini adalah tidak terdapat perbedaan peningkatan achievement motivation siswa berdasarkan jenis kelamin (gender) setelah diberi teknik self-monitoring.

\section{Metode}

Subjek penelitian ini adalah siswa SMA dengan pertimbangan alasan bahwa karakteristik siswa SMA merupakan periode transisi dari remaja menuju dewasa, pada 
periode inilah mereka rentan penyimpangan perilaku salah satunya adalah masalah rendahnya achievement motivation siswa.

Penelitian ini menggunakan rancangan experimental research, desain penelitian menggunakan one grup prestest and posttest design yang di adaptasi dari Creswell, (2009; 2012); Lodico., Spaulding dan Voegtle (2006); Cohen., Manion dan Morrison (2007). Desain ini digunakan untuk mengetahui dan menguji seberapa besar peningkatan achievement motivation siswa perempuan dan laki-laki sebelum dan sesudah diberi teknik self-monitoring, kemudian hasil tes awal dan akhir akan dibandingkan untuk mengetahui ada tidaknya perbedaan hasil tes. Variabel penelitian terdiri independent variabel $(\mathrm{X})$ yaitu teknik self-monitoring dan dependent variabel (Y) yaitu achievement motivation.

Lokasi penelitian dilaksanakan di SMAN 03 Kota Bengkulu. Pemilihan lokasi penelitian didasari dari hasil data prapenelitian yang diperoleh dari hasil wawancara dan pengamatan peneliti dimana menunjukkan terdapat siswa dengan achievement motivation rendah. Subjek penelitian adalah siswa kelas XI berjumlah 10 siswa terdiri dari 5 siswa lakilaki dan 5 siswa perempuan, subjek diambil berdasarkan karakteristik yaitu mereka yang memiliki achievement motivation rendah berdasarkan hasil pretest. Penentuan subjek menggunakan teknik purposive sampling. Instrumen penelitian menggunakan skala achievement motivation dan panduan teknik self-monitoring. Validitas instrumen skala achievement motivation melalui analisis faktor eksploratori CPA (component principal analysis) dan validitas instrumen panduan teknik self-monitoring menggunakan validasi ahli (expert judgment). Analisis data menggunakan analisis statistik dengan wilcoxom signed rank test, penelitian ini menggunakan analisis nonparametrik dengan mempertimbangkan ukuran (jumlah) subjek relatif kecil (10 subjek).

\section{Hasil/Temuan}

Deskripsi hasil/temuan penelitian memaparkan hasil/temuan 1) pengujian hipotesis, 2) lembar pantau diri selfmonitoring, 3) pengukuran skala teknik selfmonitoring (posttest), 4) rata-rata peningkatan, 5) dan perbedaan peningkatan achievement motivation siswa berdasarkan jenis kelamin (gender).

\section{Hasil Pengujian Hipotesis Penelitian}

Pengujian hipotesisi menggunakan wilcoxon signed ranks test. Keputusan pengambilan dalam pengujian hipotesis dengan kriteria jika nilai probabilitas $>0,05$, maka $\mathrm{H}_{0}$ diterima, sebaliknya jika nilai probabilitas < 0,05, maka $\mathrm{H}_{0}$ ditolak. Hasil pengujian hipotesis dipaparkan pada tebel di bawah ini.

Tabel 1.1 Hasil Wilcoxon Signed Ranks Test Test Statistics ${ }^{\mathrm{a}}$

\begin{tabular}{cr}
\hline & Posttest - Pretest \\
\hline $\mathrm{Z}$ & $-2.701^{\mathrm{b}}$ \\
\hline
\end{tabular}

Asymp. Sig. (2tailed)

.005

a. Wilcoxon Signed Ranks Test

b. Based on negative ranks.

Dari hasil wilcoxon signed ranks test, temuan menunjukkan uji statistik menghasilkan nilai $Z$ sebesar -2.701 dengan probabilitas sebesar 0.005. Hasil hitung menunjukkan $\mathrm{H}_{0}$ ditolak dan $\mathrm{H}_{1}$ diterima ( $\mathrm{F}$ 
Prio Utomo dan Zubaidah Self-monitoring Techniques: Perbedaan Peningkatan Achievement Motivation Siswa SMA Berdasarkan Jenis Kelamin (Gender)

hitung asym. Sig. (2-tailed) 0,005 <0,05 maka $\mathrm{H}_{0}$ ditolak), hal ini berarti tidak terdapat perbedaan peningkatan achievement motivation siswa berdasarkan jenis kelamin setelah diberi teknik self-monitoring. Hasil menunjukkan tidak terdapat berbedaan peningkatan achievement motivation siswa berdasarkan jenis kelamin (gender).

\section{Peningkatan Achievement Motivation Siswa Melalui Lembar Pantau Diri Self- monitoring}

Berdasarkan hasil pantau diri selfmonitoring secara keseluruhan (rekapitulasi), temuan menunjukkan perkembangan achievement motivation siswa mengalami peningkatan secara berkala, hal ini dapat dilihat dari hasil analisis data (analysis of data) menunjukkan adanya perkembangan kemajuan pada subjek melalui perilaku belajarnya. Rekapitulasi perkembangan kemampuan subjek dijabarkan pada tabel 1.2 di bawah ini.

Tabel 1.2 Rekapitulasi Perkembangan Peningkatan Achievement Motivation Siswa Laki-laki dan Perempuan Melalui Lembar Pantau Diri Self-monitoring

\begin{tabular}{|c|c|c|c|c|c|c|c|c|c|c|c|c|c|}
\hline \multirow[t]{2}{*}{$\begin{array}{c}\text { Subjek } \\
\text { Penelitian }\end{array}$} & \multirow[t]{2}{*}{$\begin{array}{c}\text { Jenis } \\
\text { Kelamin }\end{array}$} & \multicolumn{3}{|c|}{ Minggu ke } & \multicolumn{3}{|c|}{$\begin{array}{l}\text { Minggu ke } \\
\text { II }\end{array}$} & \multicolumn{3}{|c|}{ Minggu ke III } & \multicolumn{3}{|c|}{$\begin{array}{l}\text { Minggu ke } \\
\text { IV }\end{array}$} \\
\hline & & 1 & 2 & 3 & 1 & 2 & 3 & 1 & 2 & 3 & 1 & 2 & 3 \\
\hline Subjek ANA & $\mathrm{P}$ & $\sqrt{ }$ & & & & $\sqrt{ }$ & & & $\sqrt{ }$ & & & & $\sqrt{ }$ \\
\hline Subjek AZ & $\mathrm{P}$ & $\sqrt{ }$ & & & & $\sqrt{ }$ & & & $\sqrt{ }$ & & & & $\sqrt{ }$ \\
\hline Subjek AR & $\mathrm{L}$ & $\sqrt{ }$ & & & & $\sqrt{ }$ & & & & $\sqrt{ }$ & & & $\sqrt{ }$ \\
\hline Subjek ANH & $\mathrm{P}$ & $\sqrt{ }$ & & & & $\sqrt{ }$ & & & $\sqrt{ }$ & & & & $\sqrt{ }$ \\
\hline Subjek HAA & $\mathrm{L}$ & $\sqrt{ }$ & & & & $\sqrt{ }$ & & & $\sqrt{ }$ & & & & $\sqrt{ }$ \\
\hline Subjek RAA & $\mathrm{L}$ & $\sqrt{ }$ & & & & $\sqrt{ }$ & & & & $\sqrt{ }$ & & & $\sqrt{ }$ \\
\hline Subjek SVT & $\mathrm{P}$ & $\sqrt{ }$ & & & & $\sqrt{ }$ & & & $\sqrt{ }$ & & & & $\sqrt{ }$ \\
\hline Subjek DAS & $\mathrm{L}$ & $\sqrt{ }$ & & & & $\sqrt{ }$ & & & $\sqrt{ }$ & & & & $\sqrt{ }$ \\
\hline Subjek SA & $\mathrm{P}$ & $\sqrt{ }$ & & & & $\sqrt{ }$ & & & & $\sqrt{ }$ & & & $\sqrt{ }$ \\
\hline Subjek IA & $\mathrm{L}$ & $\sqrt{ }$ & & & & $\sqrt{ }$ & & & & $\sqrt{ }$ & & & $\sqrt{ }$ \\
\hline
\end{tabular}

Keterangan: 1=Rendah, 2=Sedang, $3=$ Tinggi

Dari hasil rekapitulasi perkembangan achievement motivation siswa pada tabel di atas, menunjukkan bahwa pada minggu ke I achievement motivation subjek ANA (P), AZ (P), AR (L), ANH (P), HAA (L), RAA (L), SVT (P), DAS (L), SA (P), IA (L) berada pada kategori rendah. Pada minggu ke II achievement motivation subjek ANA (P), AZ (P), AR (L), ANH (P), HAA (L), RAA (L), SVT (P), DAS (L), SA (P), IA (L) meningkat pada kategori sedang. Pada minggu ke III achievement motivation subjek ANA (P), AZ (P) berada pada kategori sedang; subjek AR (L) berada pada kategori tinggi; subjek ANH
(P), HAA (L) berada pada kategori sedang; subjek RAA (L) berada pada kategori tinggi; subjek SVT (P), DAS (L) berada pada kategori sedang; subjek SA (P), IA (L) berada pada kategori tinggi. Hasil lembar pantau diri self-monitoring menunjukkan terjadi peningkatan achievement motivation pada kategori tinggi pada minggu ke IV.

\section{Peningkatan Achievement Motivation Siswa Dari Hasil Pengukuran (Posttest)}

Dari hasil pengukuran posttest temuan menunjukan terdapat peningkatan achievement motivation pada subjek dari 
rendah menjadi sedang dan tinggi setelah diberi teknik self-monitoring. Rekapitulasi melalui skala achievement motivation dapat peningkatan achievement motivation siswa dipaparkan pada grafik 1.1 di bawah ini.

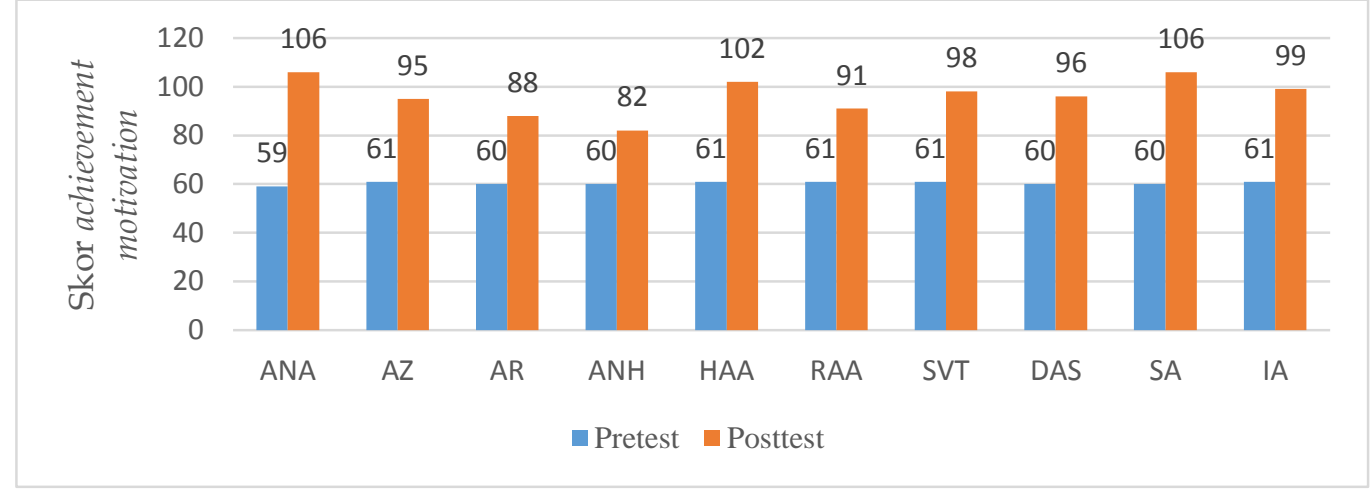

$$
\text { Tinggi }=94-124 \quad \text { Sedang }=62-93 \quad \text { Rendah }=31-61
$$

Grafik 1.1 Peningkatan Achievement Motivation Siswa Perempuan dan Laki-laki Melalui Skala Achievement Motivation

Berdasarkan grafik di atas, hasil menunjukkan bahwa terdapat peningkatan achievement motivation pada seluruh subjek setelah diberi teknik self-monitoring. Rekapitulasi peningkatan achievement motivation subjek dari hasil preetast dan posttest dipaparkan berikut; subjek ANA dari kategori rendah (skor 59) meningkat pada kategori tinggi (skor 106), subjek AZ dari kategori rendah (skor 61) meningkat pada kategori tinggi (skor 95), subjek AR dari kategori rendah (skor 60) meningkat pada kategori sedang (skor 88), subjek ANH dari kategori rendah (skor 60) meningkat pada kategori sedang (skor 82), subjek HAA dari kategori rendah (skor 61) meningkat pada kategori tinggi (skor 102), subjek RAA dari kategori rendah (skor 61) meningkat pada kategori tinggi (skor 91), subjek SVT dari kategori rendah (skor 61) mening-kat pada kategori tinggi (skor 98), subjek DAS dari kategori rendah (skor 60) meningkat pada kategori tinggi (skor 96), subjek SA dari kategori rendah (skor 60) meningkat pada kategori tinggi (skor 106), subjek IA dari kategori rendah (skor 61) meningkat pada kategori sedang (skor 99). Hasil temuan menunjukkan bahwa terdapat tujuh sub jek (ANA, AZ, HAA, SVT, DAS, SA, IA) meningkat pada kategori tinggi, dan terdapat tiga subjek (AR, ANH, RAA) meningkat pada katgori sedang.

\section{Rata-rata Peningkatan Achievement Motivation Siswa Sebelum dan Sesudah Diberi Teknik Self-Monitoring}

Dilihat dari nilai rata-rata peningkatan achievement motivation siswa sebelum (pretest) dan sesudah (posttest diberi treatment menunjukkan terdapat peningkatan achievement motivation siswa setelah diberi teknik self-monitoring. Hasil rata-rata peningkatan achievement motivation siswa pada dijabarkan pada grafik 1.2 di bawah ini. 


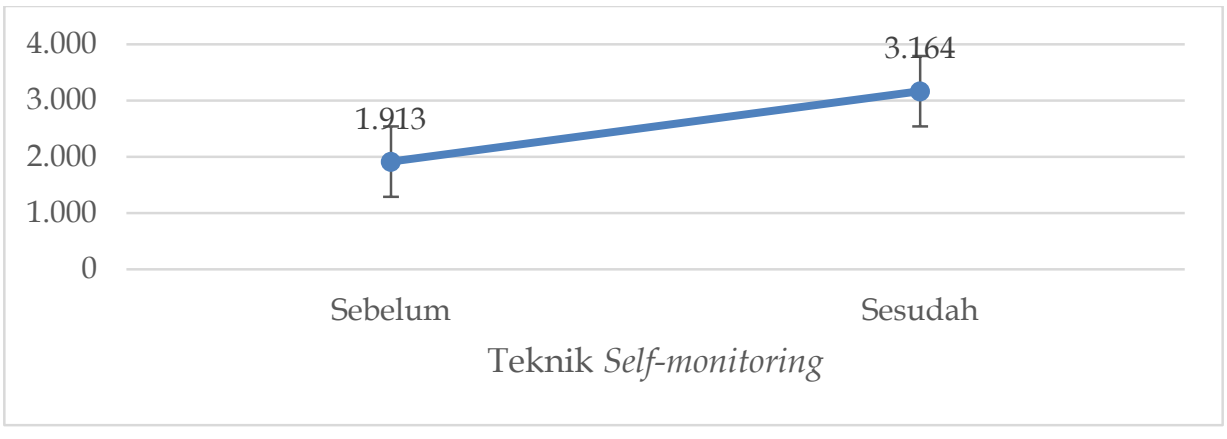

Grafik 1.2 Rata-rata Tingkat Achievement Motivation Siswa Sebelum dan Sesudah diberi Teknik Self-monitoring.

Berdasarkan grafik rata-rata tingkat achievement motivation siswa di atas. Hasil menunjukkan bahwa terdapat peningkatan achievement motivation siswa sebelum (pretest) dan sesudah (posttest) diberi teknik self-monitoring. Rata-rata signifikasi achievement motivation siswa sebelum diberi teknik self-monitoring sebesar 1,913, kemudian setelah diberi teknik selfmonitoring rata-rata signifikasi achievement motivation siswa sebesar 3,164. Hasil tersebut menunjukkan terdapat peningkatan achievement motivation siswa sebelum dan sesudah diberi teknik self-monitoring.

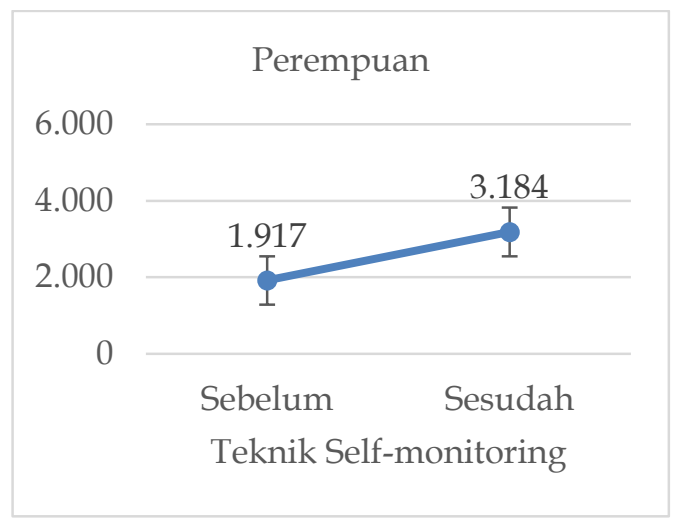

Grafik 1.3 Rata-rata Tingkat Achievement Motivation Berdasarkan Jenis Kelamin (Gender)

\section{Perbedaan Peningkatan Achievement Motivation Siswa Berdasarkan Jenis Kelamin (Gender)}

Dilihat berdasarkan jenis kelamin (gender) hasil temuan menunjukkan bahwa tidak terdapat perbedaan peningkatan achievement motivation antara siswa perempuan dan laki-laki secara signifikan, hasil temuan menunjukkan peran jenis kelamin tidak mempengaruhi terhadap peningkatan achievement motivation pada siswa laki-laki dan perempuan. Ppeningkatan achievement motivation siswa berdasarkan jenis kelamin (gender) dijabarkan pada grafik 1.3 di bawah ini.

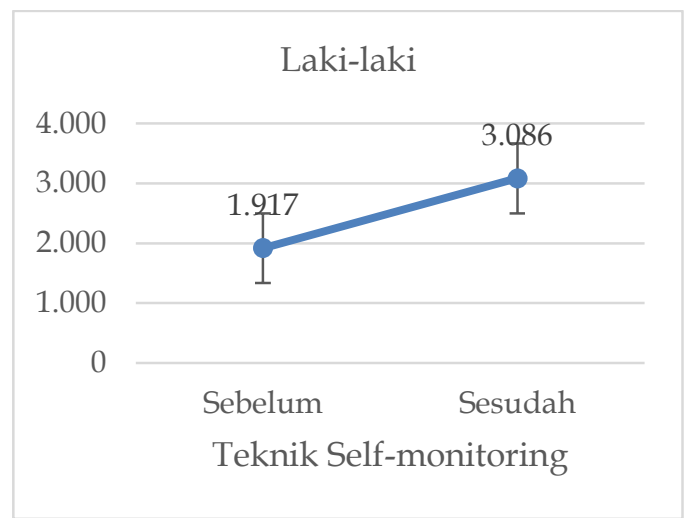


Berdasarkan grafik di atas. Temuan menunjukkan tidak terdapat perbedaan peningkatan secara signifikan antara siswa berdasarkan jenis kelamin (gender). Hasil menunjukkan rata-rata peningkatan achievement motivation siswa perempuan sebelum diberi teknik self-monitoring sebesar 1,922, dan rata-rata peningkatan achievement motivation siswa laki-laki sebelum diberi teknik self-monitoring sebesar 1,931. Setelah di beri teknik self-monitoring rata-rata peningkatan achievement motivation siswa perempuan sebesar 3,184 dan rata-rata peningkatan achievement motivation siswa laki-laki sebesar 3,086. Hasil tersebut menunjukkan tidak terdapat perbedaan peningkatan achievement motivation siswa perempuan dan laki-laki sebelum dan sesudah diberi teknik self-monitoring dimana nilai rata-rata peningkatan hampir sama dan tidak terdapat perbedaan yang signifikan antara siswa laki-laki dan perempuan. Hal ini berarti peran jenis kelamin (gender) tidak mempengaruhi terhadap peningkatan achievement motivation siswa.

\section{Pembahasan}

Hasil/temuan penelitian mengungkap bahwa tidak terdapat perbedaan peningkatan achievement motivation siswa berdasarkan jenis kelamin (gender). Dilihat dari hasil lembar pantau diri self-monitoring, menunjukkan bahwa terjadi peningkatan achievement motivation siswa laki-laki dan perempuan pada kategori tinggi pada minggu ke IV. Hasil pantau diri selfmonitoring secara keseluruhan (rekapitulasi) menunjukkan terdapat perkembangan dan kemajuan achievement motivation pada siswa, hasil analysis of data menunjukkan adanya perkembangan kemajuan pada subjek dalam perilaku belajarnya. Dari hasil pengukuran skala achievement motivation menunjukan adanya peningkatan achievement motivation dari rendah menjadi sedang dan tinggi setelah diberi teknik self-monitoring. Ratarata peningkatan achievement motivation siswa perempuan dan laki-laki menunjukkan nilai rata-rata peningkatan hampir sama dan tidak terdapat perbedaan yang signifikan antara siswa laki-laki dan perempuan, hal ini berarti peran jenis kelamin (gender) tidak mempengaruhi terhadap peningkatan achievement motivation.

Selama proses pelaksanaan teknik selfmonitoring, pada proses discrimination of a response, siswa dapat mendiskripsikan masalah rendahnya achievement motivation pada diri, penyebab terjadinya dan dampak sebagai hasil dari perilaku belajar yang salah. Pada proses recording of a response, siswa dapat mencatat atau merekam segala bentuk perilaku belajar yang dilakukannya dan pengalaman perilaku belajar yang salah, penyebab achievement motivation menjadi rendah, serta dampak yang dihasilkan. Pada proses charting of a response siswa dapat memetakkan perilaku belajar ke dalam bentuk grafik peningkatan belajar, hasil menunjukkan masing-masing siswa dapat dengan baik memetakan ke dalam bentuk grafik perilaku belajar minggu I, II, III, IV dan seterusnya. Pada proses displaying of data siswa dapat menyajikan grafik perilaku belajar, membuat daftar cek mandiri untuk memantau hasil yang disajikan apakah sudah sesuai dengan perilaku yang dilakukan dan melakukan evaluasi diri untuk mengatasi temuan kendala selama proses pencatatan perilaku belajar. Pada 
Prio Utomo dan Zubaidah Self-monitoring Techniques: Perbedaan Peningkatan Achievement Motivation Siswa SMA Berdasarkan Jenis Kelamin (Gender)

proses analysis of data siswa dapat mengintepretasi data hasil perkembangan peningkatan belajarnya.

Setelah siswa diberi teknik selfmonitoring, pada implementatifnya tujuan self-monitoring dalam usaha meningkatkan achievement motivation siswa adalah agar siswa dapat membuat keputusan untuk terlibat dalam pemantauan diri (make the decision to engage in self-management); menentukan target perilaku dan perilaku bersaing (define the target behavior and competing behaviors); menetapkan tujuan (set goals); memonitor diri (self-monitoring); melakukan penilaian fungsional (conduct $a$ functional assessment); strategi manajemen diri secara tepat (choose appropriate selfmanagement strategies); mengevaluasi perubahan (evaluate change); mengevaluasi kembali strategi manajemen diri (reevaluate self-management strategies); dan menerapkan strategi pemeliharaan (implement maintenance strategies) (Miltenberger, 2008).

Efektifitas teknik self-monitoring pada dasarnya adalah pengajaran bagaimana siswa dapat melakukan monitoring diri, mereka belajar bagaimana cara mengamati dan merekam diri. Melalui pengamatan individu menjadi sadar ada atau tidak adanya perilaku sasaran. Melalui rekaman diri, individu dapat mencatat terjadinya perilaku (Maag dalam Allinder, et. al, 2000). Self-monitoring merupakan proses dimana konseli mengamati dan mencatat hal-hal tentang diri mereka sendiri dan interaksi dengan situasi lingkungannya (Cormier dan Nurius, 2003). Penggunaan teknik selfmonitoring sebagai suatu prosedur sistematis yang dilakukan siswa dengan cara memonitor perilaku mereka sendiri untuk menilai apakah suatu perilaku yang ditargetkan telah terjadi, proses monitoring ini dilakukan melalui beberapa cara tertentu O'Reilly, et. al, 2002; Wilkinson, 2008; (dalam Holifield, et. al, 2010). Senada menurut Ciminero, et. al (dalam Cormier dan Nurius, 2003) menjabarkan teknik self-monitoring dilakukan untuk mengevaluasi tujuan dan hasil, memonitor target perilakunya baik itu sebelum atau selama program treatment, dan monitoring hasil penilaian dan pengumpulan data. Teknik self-monitoring diajarkan kepada siswa berupa proses pemantauan diri dalam bentuk pencatatan maupun perekaman diri melalui prosedur sistematis dari perilaku yang dilakukannya. Levendoski dan Cartledge mengemukakan teknik self-monitoring merupakan proses yang mengarahkan pada pengaturan diri, mempromosikan karakteristik pada diri serta motif sosial yang signifikan dari setiap kompetensi dan independensi ( $\mathrm{O}^{\prime}$ Reilly, et. al, (2002). Senada menurut pendapat Graham, Harris, Reid dan Maag mendefinisikan teknik self-monitoring merupakan komponen pemantauan diri yang mencakup dua jenis; pengamatan diri, individu mengamati secara sadar ada atau tidak dari perilaku sasaran yang dibuatnya. Perekaman diri, individu mencatat perilaku yang dilakukannya (Allinder, et. al, 2000).

Hasil temuan penelitian ini memiliki relevansi dengan hasil penelitian terdahulu oleh Dwindita Hildayani (2019); Dewantara dan Ardilla (2018), Megawati (2017); Pradana (2017) menunjukkan bahwa teknik self-monitoring efektif dapat digunakan sebagai salah satu treatment. Sejalan dengan hasil temuan penelitian ini, peningkatan achievement motivation siswa ditengarai 
bahwa peranan teknik self-monitoring merupakan sebuah treatment yang bertujuan agar siswa dapat memantau perilaku yang dilakukannya apakah dapat memenuhi dari target yang diinginkan, pemantauan ini dilakukan dalam bentuk pencatatan maupun perekaman. Disamping itu, aspek penting peran penggunaan teknik selfmonitoring efektif meningkatkan achievement motivation siswa ditengarai bahwa peran penggunaan teknik ini menekankan pada proses bagaimana siswa dapat memantau perilaku yang dilakukannya dan seberapa besar perubahan perilaku dari target yang dihasilkan. Peranan teknik self-monitoring sebagai suatu strategi perubahan perilaku yang dilakukan secara terukur yaitu melalui pencatatan dan perekaman yang mana di dalam prosesnya siswa mengarahkan perubahan perilakunya sendiri dengan melakukan pencatatan/perekaman ulang untuk mencapai target yang diinginkan. Aspek lain keutamaan inti teknik ini efektif meningkatkan achievement motivation siswa adalah teknik self-monitoring menekankan pada regulasi pembelajaran diri, dan proses mengorganisir perilaku belajar yang dilakukannya melalui pencatatan maupun perekaman.

\section{Kesimpulan}

Berdasarkan pengujian penelitian, hasil hitung diperoleh $\mathrm{H}_{0}$ ditolak dan $\mathrm{H}_{1}$ diterima hal ini berarti tidak terdapat perbedaan peningkatan achievement motivation siswa berdasarkan jenis kelamin (gender) setelah diberi teknik self-monitoring. Hasil temuan penelitian menunjukkan tidak terdapat perbedaan peningkatan achievement motivation siswa berdasarkan jenis kelamin setelah diberi teknik self-monitoring, hasil temuan menunjukkan peran jenis kelamin (gender) tidak memberikan pengaruh terhadap secara signifikan peningkatan achievement motivation siswa baik itu siswa laki-laki maupun perempuan.

Keterbatasan penelitian ini antara lain; 1) penelitian ini hanya memfokuskan pada siswa yang memiliki achievement motivation rendah saja; 2) jumlah subjek penelitian hanya 10 siswa sehingga analisis data menggunakan analisis nonparametrik; 3) setting penelitian ini dilaksanakan pada jenjang SMA; 4) penggunaan teknik selfmonitoring memfokuskan pada tindakan kuratif (penyelesaian) tidak pada tindakan preventif (pencegahan).

Rekomendasi/saran hasil penelitian antara lain 1) hasil penelitian ini dapat dijadikan novelty penelitian; 2) memfokuskan pada tindakan preventif (pencegahan); 3) memfokuskan pada treatment individual.

\section{Daftar Pustaka}

Allinder, R.M., Bolling., R.M., Oats, R.G. \& Gagnon, W.A. (2000). Effects of Teacher Self-Monitoring on Implementation of Curriculum-Based Measure-ment and Mathematics Computation Achievement of Students with Disa-bilities. Remidial and Special Education. Vol. 21, (4): 219226.

Aziroh, L.F. (2018). Pengaruh Regulasi Diri dan Motivasi Berprestasi Terhadap Perilaku Mencontek Siswa-Siswi MTs Miftahul Huda Bulungan Pakis Aji Jepara. Semarang: UIN Walisongo. 
Prio Utomo dan Zubaidah

Self-monitoring Techniques: Perbedaan Peningkatan Achievement Motivation Siswa SMA Berdasarkan

Jenis Kelamin (Gender)

Cohen, L., Manion, L. \& Morrison, K. (2007). Research Methods in Education. Sixth edition. New York: Routledge Taylor \& Francis Group.

Cormier, S. \& Nurius, P. (2003). Interviewing and Change Strategies for Helpes: Fundamental Skills and Cognitive Behavioral Interventions. USA: Thomsom Brooks/Cole.

Cormier, S., Nurius, P. \& Obsborn, C. (2009). Interviewing and Change Strategies for Helpes: Fundamental Skills and Cognitive Behavioral Interventions. USA: Brooks/Cole.

Creswell, J.W. (2009). Research Design Qualitative, Quantitative, and Mixed Methods Approaches. Third edition. University of Nebraska-Lincoln: SAGE Publications.

Dewantara, B.M dan Ardilla, F. 2018. Selfmonitoring, Failure-Detection and Decision-Making System to Support ETrashBot (EEPIS Trash Bin Tobat) Operation: Primary Report. International Conference on Information technology and Electrical Enginering (ICITEE), 1-6, 2018.

Dwindita, M dan Hildayani, R. (2019). Penerapan Teknik Self-Monitoring Untuk Meningkatkan Perilaku OnTask Pada Anak Underachiever: Sebuah Studi Kasus. Seurune, Jurnal Psikologi Unsyiah. Vol 2, No. 2, Juli 2019.

Holifield, C., et. al. (2010). Using Self Monitoring to Increase Attending to Task and Academic Accuracy in Children With Autism. Hammill
Institute on Disabilities. Vol. 25, (4): 230238.

Isnannisa, E.D dan Hildayani, R. (2019). Efektivitas Self Monitoring untuk Meningkatkan Perilaku On-Task pada Anak dengan Attention Deficit Hyperactivity Disorder. Jurnal Psikogenesis, Volume 7, No.2, Desember 2019.

Levendoski, L.S. \& Cartledge, G. (2000). Selfmonitoring for Elementary School Children with Serious Emotional Disturbances: Classroom Applications for Increased Academic Responding. Journah of Behavioral Disorders, Vol. 25, 211-224.

Lodico, M.G., Spaulding, D.T dan Voegtle, K.H. (2006). Methods in Educational Research: From Theory to Practice. San Francisco: John Wiley \& Sons, Inc.

Megawati, W. 2017. Penerapan Selfmonitoring Dalam Meningkatkan Hasil belajar Matematika Siswa Pada Materi Fungsi Komposisi dan Invers Suatu Fungsi Kelas XI IPS SMA PMDS Putri Palopo. Gorontalo: IAIN Palopo.

Miltenberger, R.G. (2008). Behavior Modification: Principles and Procedures, Fourth Edition. USA: Thomson Learning, Inc.

OECD. (2012). PISA (Programme for International Student Assessment). Results in Focus: What 15-year-olds Know and What They Can Do With What They Know. (Online): (www.oecd.org/pisa).

O'Reilly, M.F., et. al. (2002). Using a problem-solving approach to teach 
classroom skills to a student with moderate intellectual disabilities within regular classroom settings. International Journal of Disability, Development and Education, Vol. 49, 95104.

Peacock, G.G., et. al. (2010). Practical Handbook of School Psychology: Effective Practices for the 21st Century. New York: The Guilford Press.

Pradana, H.W. 2017. Panduan Pengembangan Kebiasaan Perilaku Melayani Dengan Teknik Selfmonitoring pada Peserta Didik Sekolah Menengah Atas (SMA) Se-eks Karesidenan Surakarta. Surakarta: UNS.

Putra, A.A.G.A.D., Suarni, N.K dan Dharsana, I. K. (2019). Efektivitas Teknik Pemantauan Diri untuk Meningkatkan Keteraturan Diri Siswa. Bisma The Journal of Counseling. Volume 3 Number 1, 2019, pp 25- 30.

Rugian, V.E. (2019). Hubungan antara Pola Asuh Orang Tua dan Motivasi berprestasi dengan Hasil Belajar Matematika Siswa Kelas V SDN Gugus Cakra Semarang. Semarang: Universitas negeri Semarang.

Schunk., D.H., Pintrick, P.R. \& Mee, J.L. (2008). Motivation in Education: Theory Research and Application ( $3^{\text {rd }} E d$ ). New Jersey: pearson Education, Inc.
Singh, K. (2011). Study of Achievement Motivation in Relation to Academic Achievement of Students. International Journal of Educational Planning dan Administration. Vol. 1, (2): 161-171.

Setiarto R.A. (2020) Hubungan antara AQ (Adversity Quotient) dengan Motivasi Berprestasi pada Siswa MTsN 8 Madiun. Surabaya: UIN Sunan Ampel.

Suryana, I.M.Y., Santyasa, I.W dan Gunadi, I.G.A. (2019). Keefektifan Model Based Learning dan Motivasi Berprestasi Siswa dalam Pencapaian Prestasi Belajar Fisika. Mimbar Pendidikan 4 (1) 35-54.

Tirto.id. (2019). Alasan Mengapa Kualitas PISA Siswa Indonesia Buruk. (Online): https://tirto.id/alasan-mengapakualitas-pisa-siswa-indonesia-burukenfy. Desember 2019.

Widyanti, R. N. (2019). Student Perception of Quality of Service in The Master of Management Study Program of Yogyakarta University of Technology. Journal of Business Management. Online:

https://doi.org/10.18196/mb.10179

Wilkinson, L.A. (2008). Self-management for Children with High Functioning Autism Spectrum Disorders. Intervention in School and Clinic, Vol. 43, 150-157. 